\title{
Functional Heterogeneity and Therapeutic Targeting of Tissue-Resident Memory T Cells
}

\author{
Esmé T. I. van der Gracht (D), Felix M. Behr and Ramon Arens* \\ Department of Immunology, Leiden University Medical Center, 2333 ZA Leiden, The Netherlands; \\ E.T.I.van_der_Gracht@lumc.nl (E.T.I.v.d.G.); F.M.Behr@lumc.nl (F.M.B.) \\ * Correspondence: R.Arens@lumc.nl; Tel.: +31-(71)-5266704
}

check for updates

Citation: van der Gracht, E.T.I.; Behr,

F.M.; Arens, R. Functional

Heterogeneity and Therapeutic

Targeting of Tissue-Resident Memory

T Cells. Cells 2021, 10, 164. https://

doi.org/10.3390/cells10010164

Received: 4 December 2020

Accepted: 13 January 2021

Published: 15 January 2021

Publisher's Note: MDPI stays neutral with regard to jurisdictional clai$\mathrm{ms}$ in published maps and institutional affiliations.

Copyright: $(\odot 2021$ by the authors. Licensee MDPI, Basel, Switzerland. This article is an open access article distributed under the terms and conditions of the Creative Commons Attribution (CC BY) license (https:// creativecommons.org/licenses/by/ $4.0 /)$.

\begin{abstract}
Tissue-resident memory $\mathrm{T}\left(\mathrm{T}_{\mathrm{RM}}\right)$ cells mediate potent local innate and adaptive immune responses and provide long-lasting protective immunity. $\mathrm{T}_{\mathrm{RM}}$ cells localize to many different tissues, including barrier tissues, and play a crucial role in protection against infectious and malignant disease. The formation and maintenance of $\mathrm{T}_{\mathrm{RM}}$ cells are influenced by numerous factors, including inflammation, antigen triggering, and tissue-specific cues. Emerging evidence suggests that these signals also contribute to heterogeneity within the $\mathrm{T}_{\mathrm{RM}}$ cell compartment. Here, we review the phenotypic and functional heterogeneity of $\mathrm{CD}^{+} \mathrm{T}_{\mathrm{RM}}$ cells at different tissue sites and the molecular determinants defining $C D 8^{+} \mathrm{T}_{\mathrm{RM}}$ cell subsets. We further discuss the possibilities of targeting the unique cell surface molecules, cytokine and chemokine receptors, transcription factors, and metabolic features of $\mathrm{T}_{\mathrm{RM}}$ cells for therapeutic purposes. Their crucial role in immune protection and their location at the frontlines of the immune defense make $T_{\mathrm{RM}}$ cells attractive therapeutic targets. A better understanding of the possibilities to selectively modulate $\mathrm{T}_{\mathrm{RM}}$ cell populations may thus improve vaccination and immunotherapeutic strategies employing these potent immune cells.
\end{abstract}

Keywords: T cells; heterogeneity; tissue residency; immunotherapy; therapeutic targeting

\section{Introduction}

$\mathrm{CD}^{+} \mathrm{T}$ cells play a crucial role in immune protection against pathogens and cancer [1] Upon antigen recognition following vaccination or infection, naïve antigen-specific CD8 ${ }^{+}$ $T$ cells clonally expand and differentiate into effector cell populations. After an initial proliferative expansion, effector T cells eventually differentiate into phenotypically diverse memory $\mathrm{CD}^{+} \mathrm{T}$ cell subsets. Central memory $\mathrm{T}\left(\mathrm{T}_{\mathrm{CM}}\right)$ cells are characterized by expression of the lymph node homing molecules CD62L and CCR7, which enable them to patrol secondary lymphoid organs, whereas effector memory $\mathrm{T}\left(\mathrm{T}_{\mathrm{EM}}\right)$ cells lack these homing molecules and circulate throughout the body [2]. In addition to the circulating $\mathrm{T}_{\mathrm{CM}}$ and $\mathrm{T}_{\mathrm{EM}}$ cells, tissue-resident memory $\mathrm{CD}^{+} \mathrm{T}\left(\mathrm{T}_{\mathrm{RM}}\right)$ cells form an integral part of the memory $\mathrm{T}$ cell pool. In contrast to their circulating counterparts, $\mathrm{T}_{\mathrm{RM}}$ cell populations localize to peripheral tissues and lymphoid organs, where they reside with minimal egress [3-5]. $\mathrm{T}_{\mathrm{RM}}$ cells are characterized by the expression of tissue retention molecules, such as CD69, and downregulation of genes involved in tissue egress, including S1pr1 and Ccr7 [6]. Upon restimulation, $\mathrm{T}_{\mathrm{RM}}$ cells rapidly release effector molecules, such as interferon- $\gamma(\mathrm{IFN}-\gamma)$, tumor necrosis factor (TNF), and granzyme B; initiate proliferation; and induce recruitment of other immune cells to the site of challenge $[7,8]$. $\mathrm{T}_{\mathrm{RM}}$ cells are found in a large variety of tissues and mediate potent local innate and adaptive immunity against pathogens and tumors $[9,10]$.

Defining the crucial molecular interactions and mechanisms that induce effective CD8 ${ }^{+}$ $\mathrm{T}$ cell memory pools at the right location is critical for the design of successful vaccines against cancer and infectious disease. Here, we review the heterogeneous phenotypes and functions of $\mathrm{CD}^{+} \mathrm{T}_{\mathrm{RM}}$ cells and how their unique characteristics, including cell surfaces 
molecules, cytokine and chemokine receptors, transcription factors, and metabolic features, can be targeted to improve immunotherapies.

\section{2. $T_{R M}$ Cell Formation and Maintenance}

2.1. $T_{R M}$ Cell Formation

Both $\mathrm{CD} 8^{+} \mathrm{T}_{\mathrm{RM}}$ cells and circulating memory $\mathrm{T}$ cells appear to arise primarily from the KLRG1 ${ }^{\text {lo }}$ IL-7R $\alpha^{\text {hi }}$ memory precursor effector cell pool [6,11]. However, it remains incompletely understood at which stage the tissue-resident and circulating lineages separate. Transcriptional analysis revealed that the gene expression profile of $T_{R M}$ cells is already largely established in effector $\mathrm{CD} 8^{+} \mathrm{T}$ cells at peripheral tissue sites during the effector phase after infection, indicating a role of the tissue microenvironment in instructing $\mathrm{T}_{\mathrm{RM}}$ cell formation [11]. The development of $\mathrm{T}_{\mathrm{RM}}$ cells is shaped by the cytokine milieu, with the cytokines IL-12, type I IFN, and IL-15 playing important roles in the differentiation of these memory $\mathrm{T}$ cells [12-14]. In addition, various transcription factors, including Hobit and its homolog Blimp-1 as well as Runx3, Notch, and Bhlhe40, regulate CD8 ${ }^{+} \mathrm{T}_{\mathrm{RM}}$ cell development [11,15-17]. Blimp-1 and Hobit mediate tissue retention of CD8 ${ }^{+} \mathrm{T}_{\mathrm{RM}}$ cells by suppressing tissue egress pathways. These transcription factors regulate the tissue residency of $\mathrm{CD}^{+} \mathrm{T}_{\mathrm{RM}}$ cells and other tissue-resident lymphocyte populations, including liver-resident natural killer T (NKT) cells and type 1 innate lymphoid cells (ILC1s) [17]. Transcriptional regulation of $\mathrm{T}_{\mathrm{RM}}$ cells is further characterized by tissue-specific adaptations $[6,17]$. $\mathrm{CD}^{+} \mathrm{T}_{\mathrm{RM}}$ cell formation in the lungs after influenza virus infection primarily depends on Blimp-1 rather than Hobit, potentially through control of the lineage choice between $\mathrm{T}_{\mathrm{CM}}$ and $\mathrm{T}_{\mathrm{RM}}$ cells during the differentiation of virus-specific $\mathrm{CD} 8^{+} \mathrm{T}$ cells [18].

\section{2. $T_{R M}$ cell Maintenance and Plasticity}

In mice, $C D 8^{+} \mathrm{T}_{\mathrm{RM}}$ cells persist in many tissues for extended periods of time, including the skin, liver, and intestine $[5,13,19]$. Experimental procedures such as parabiosis, where the blood circulation of two animals is conjoined, and transplantation experiments have demonstrated the minimal recirculation capacity of these cells under steady-state conditions $[4,5,20]$. The role of $\mathrm{T}_{\mathrm{RM}}$ cells has been studied in experimental settings involving selective depletion of these cells (e.g., by using CXCR3 antibody or NAD treatment), sequestration of circulating cells in the lymph nodes by FTY720 treatment, and comparison of settings in which $\mathrm{T}_{\mathrm{RM}}$ cells were present and/or absent in tissues prior to (local) challenges $[19,21,22]$. While research on $T_{R M}$ cells in human tissues is more challenging, studies of human tissue transplants demonstrated that $\mathrm{T}_{\mathrm{RM}}$ cells also persist in human tissues for long periods of time [23,24].

Even though $T_{R M}$ cells persist for years in many tissues, the population dynamics of $T_{R M}$ cells in specific tissues remain incompletely understood. Maintenance of $T_{R M}$ cells is influenced by the tissue microenvironment, including homeostatic cytokines such as IL-7, IL-15, and transforming growth factor- $\beta$ (TGF- $\beta$ ). In addition, maintenance of $\mathrm{CD}^{+} \mathrm{T}_{\mathrm{RM}}$ cells is regulated by tissue damage via P2RX7, a damage/danger-associated molecular pattern receptor that is triggered by extracellular nucleotides (ATP, NAD ${ }^{+}$). P2RX7 activation in vivo by exogenous $\mathrm{NAD}^{+}$or tissue damage leads to specific depletion of $\mathrm{T}_{\mathrm{RM}}$ cells while retaining circulating $\mathrm{T}$ cells [25]. The tissue microenvironment also influences the metabolic requirements of $\mathrm{CD} 8^{+} \mathrm{T}_{\mathrm{RM}}$ cells, which shape their survival and functionality. Specifically, skin $\mathrm{T}_{\mathrm{RM}}$ cells require the uptake and metabolism of exogenous free fatty acids (FFA) to persist in the tissue [26]. Following viral infection, developing $\mathrm{CD}^{+} \mathrm{T}_{\mathrm{RM}}$ cells in the skin differentially express the fatty-acid-binding proteins 4 and 5 (FABP4 and FABP5), which mediate lipid uptake and intracellular transport. Recently, Frizzell and colleagues found that $T_{R M}$ cells from different tissues show varying patterns of isoform usage of fatty-acid-binding proteins, which is determined by tissue-derived factors [27]. Together, these findings indicate that $\mathrm{T}_{\mathrm{RM}}$ cells undergo metabolic adaptations shaped by the local microenvironment. 
Local $\mathrm{CD} 8^{+} \mathrm{T}_{\mathrm{RM}}$ cell populations are further characterized by quantitative and qualitative changes following local antigen encounter. In the skin and female reproductive tract, $\mathrm{CD}^{+} \mathrm{T}_{\mathrm{RM}}$ cells undergo local proliferation in situ within days after antigen encounter $[28,29]$. Here, preexisting $\mathrm{T}_{\mathrm{RM}}$ cell populations within the peripheral tissues appear to be the primary source of both local proliferative recall responses and secondary $T_{R M}$ cells developing after reinfection [28-30]. Additionally, $\mathrm{T}_{\mathrm{RM}}$ cell reactivation triggers the recruitment of circulating memory $\mathrm{CD}^{+} \mathrm{T}$ cells into the tissue, which undergo antigenindependent $\mathrm{T}_{\mathrm{RM}}$ cell differentiation in situ. Circulating memory $\mathrm{CD} 8^{+} \mathrm{T}$ cells may differ in their capacity to form $\mathrm{T}_{\mathrm{RM}}$ cells at different tissue sites. Predominantly, $\mathrm{CD} 8^{+} \mathrm{T}_{\mathrm{EM}}$ cells are able to convert into liver $\mathrm{CD}^{+} \mathrm{T}_{\mathrm{RM}}$ cells upon adoptive transfer in the presence of antigen [31]. In contrast, both $\mathrm{T}_{\mathrm{EM}}$ and $\mathrm{T}_{\mathrm{CM}}$ cells are limited in their capacity to form $\mathrm{CD} 103^{+} \mathrm{T}_{\mathrm{RM}}$ cells at mucosal sites after reinfection [32].

More recently, a study using a unique $\mathrm{T}_{\mathrm{RM}}$ fate-mapping model demonstrated that $\mathrm{T}_{\mathrm{RM}}$ cells are able to reenter circulation upon reactivation [29]. Following pathogen rechallenge, $\mathrm{T}_{\mathrm{RM}}$ cells downregulate Hobit expression on antigen encounter and form circulating memory $\mathrm{T}$ cells. These tissue-experienced ex- $\mathrm{T}_{\mathrm{RM}}$ cells are transcriptionally and functionally distinct from secondary $\mathrm{T}_{\mathrm{EM}}$ cells. Thus, subsets of $\mathrm{T}_{\mathrm{RM}}$ cells appear to maintain recirculation capacity and thereby contribute to systemic immunity following reinfection. In line with these findings, Fonseca and colleagues found that local reactivation of $T_{R M}$ cells precipitates egress to circulation [33]. Even though these ex- $\mathrm{T}_{\mathrm{RM}}$ cells share developmental plasticity with other circulating memory subsets, they remain epigenetically poised for tissue migration and $\mathrm{T}_{\mathrm{RM}}$ cell redifferentiation. Tissue-experienced ex- $\mathrm{T}_{\mathrm{RM}}$ cells may therefore represent functional adaptions of the memory $\mathrm{CD}^{+} \mathrm{T}$ cell compartment to reinvading pathogens.

\section{3. $T_{R M}$ Cell Heterogeneity}

Transcriptional profiling has revealed a unique gene expression signature of $T_{R M}$ cells shared between $T_{R M}$ cells at various locations $[6,17]$. However, $T_{R M}$ cells in different organs are characterized by tissue-specific gene expression profiles [6,17]. Recently, two studies identified previously unknown transcriptional heterogeneity within the developing and established $\mathrm{T}_{\mathrm{RM}}$ cell compartments of the intestine, representing functionally distinct $\mathrm{T}_{\mathrm{RM}}$ subsets with divergent transcriptional programs, cytokine production, and secondary memory potential $[34,35]$. Recent evidence additionally suggests that memory CD8 ${ }^{+} \mathrm{T}$ cell heterogeneity of both circulating and $\mathrm{T}_{\mathrm{RM}}$ cells is primarily influenced by pathogen-specific cues and further shaped by the tissue microenvironment [36]. However, the functional consequences of $\mathrm{CD} 8^{+} \mathrm{T}_{\mathrm{RM}}$ cell heterogeneity remain incompletely understood.

Local inflammatory microenvironments regulate the differentiation and persistence of $\mathrm{CD}^{+} \mathrm{T}_{\mathrm{RM}}$ cells. In the intestine, TGF- $\beta$ and proinflammatory chemokines differentially control the formation of $\mathrm{CD}_{103^{+}}$and $\mathrm{CD} 103^{-} \mathrm{T}_{\mathrm{RM}}$ cell subsets with distinct localization and functionality [13]. Intestinal macrophages produce the inflammatory cytokines IL-12 and IFN- $\beta$, which drive the persistence of CD103- $\mathrm{T}_{\mathrm{RM}}$ cells, while CD103 ${ }^{+} \mathrm{T}_{\mathrm{RM}}$ cells develop independently [14]. In the lungs, a distinct subset of $\mathrm{T}_{\mathrm{RM}}$ cells in the interstitium acts as a resident reservoir and maintains airway $T_{R M}$ cells [37]. CD8 ${ }^{+} T_{R M}$ cells in the lung airways are seeded continuously by $\mathrm{T}_{\mathrm{RM}}$ cells from the lung interstitium, a process driven by the chemokine receptor CXCR6. In addition to the cytokine environment, the functional properties of $\mathrm{T}_{\mathrm{RM}}$ cells can be influenced by cellular interactions. Low et al. found that numerous hematopoietic and non-hematopoietic antigen-presenting cells were able to reactivate lung $\mathrm{T}_{\mathrm{RM}}$ cells but the quality of functional $\mathrm{T}_{\mathrm{RM}}$ cell responses, as defined by activation signatures, depended on the identity of the antigen-presenting cells [38]. In the skin, CD49a distinguishes a subset of $\mathrm{T}_{\mathrm{RM}}$ cells poised for IFN- $\gamma$ production and cytotoxic capacity while CD49a- skin $T_{R M}$ cells preferentially produce IL-17. Importantly, this functional heterogeneity between CD49a ${ }^{+}$and $\mathrm{CD} 49 \mathrm{a}^{-}$cells is preserved in inflammatory diseases such as vitiligo and psoriasis [39]. Thus, multiple factors, including the cytokine 
environment, and antigen-triggering and cellular interactions impact the heterogeneity of local $\mathrm{CD} 8^{+} \mathrm{T}_{\mathrm{RM}}$ cell populations.

\section{Functional Heterogeneity and Therapeutic Targeting}

Circulating memory $\mathrm{CD} 8^{+} \mathrm{T}$ cells are heterogeneous in their phenotype and migratory properties as well as their functions and proliferative potential [40]. As reviewed by Jameson and Wherry, the nomenclature of memory $\mathrm{T}$ cells is challenging due to the continuum of memory $\mathrm{T}$ cell properties with respect to their location and recirculation capacity, metabolism, epigenetic regulation, and longevity [41]. Hence, in addition to the main circulating $\mathrm{T}_{\mathrm{EM}}$ and $\mathrm{T}_{\mathrm{CM}}$ subsets, many more subdivisions can be defined, including but not limited to stem cell memory $\mathrm{T}\left(\mathrm{T}_{\mathrm{SCM}}\right)$ cells and exhausted $\mathrm{T}\left(\mathrm{T}_{\mathrm{EX}}\right)$ cells.

Next to the heterogeneous population of circulating memory $\mathrm{CD} 8^{+} \mathrm{T}$ cells, resident $\mathrm{CD}^{+} \mathrm{T}$ cells also display phenotypic and functional heterogeneity. $\mathrm{CD} 8^{+} \mathrm{T}_{\mathrm{RM}}$ cells can, for example, display activated phenotypes, as characterized by high amounts of markers related to costimulatory or inhibitory receptors, cytokine receptors, and/or chemokine receptors. Since $T_{R M}$ cells mediate tissue immunity, enhancing their numbers or functional properties could be beneficial for viral immunity and immunotherapy in malignant diseases.

In many human cancers, large quantities of tumor-infiltrating $\mathrm{T}_{\mathrm{RM}}$-like cells correlate with an improved overall survival [42-44]. In addition, $\mathrm{T}_{\mathrm{RM}}$ cells play a crucial role in controlling tumor outgrowth in preclinical models $[45,46]$. Here, $\mathrm{T}_{\mathrm{RM}}$ cells may amplify antitumor responses through dendritic cell activation [47]. Thus, the possibility to increase $\mathrm{T}_{\mathrm{RM}}$ cell numbers and thereby enhance local protective immunity constitutes a promising immunotherapeutic approach. An increase in $\mathrm{T}_{\mathrm{RM}}$ cell numbers may be achieved by providing antigen and/or inflammation at the desired tissue site. For instance, intranasal, but not systemic administration of live-attenuated influenza virus generates virus-specific $\mathrm{CD}^{+} \mathrm{T}_{\mathrm{RM}}$ cells in the lungs that mediate heterosubtypic protection against influenza virus infection [48]. Interestingly, lung $\mathrm{T}_{\mathrm{RM}}$-mediated protection against influenza virus was independent of circulating $\mathrm{T}$ cells and neutralizing antibodies and persisted long-term after vaccination. In preclinical models of melanoma, intradermal but not intraperitoneal vaccination generated skin $\mathrm{T}_{\mathrm{RM}}$ cells mediating strong protection against cutaneous melanoma [46]. The localized formation of $\mathrm{T}_{\mathrm{RM}}$ cells can thus provide immunity to both infectious and malignant challenges [49]. In addition, $\mathrm{T}_{\mathrm{RM}}$ cell responses could be enhanced by active recruitment of $\mathrm{T}$ cells to the site of inflammation. Local inflammation can be sufficient to induce the development of protective $\mathrm{T}_{\mathrm{RM}}$ cell populations at peripheral sites in the absence of a local antigen [50]. However, $\mathrm{T}_{\mathrm{RM}}$ cell formation is substantially enhanced in the presence of cognate antigen within the tissue microenvironment [51-53]. Similarly, sequential immunizations result in global lodgment of skin $\mathrm{T}_{\mathrm{RM}}$ cells, but active recruitment by local inflammation or infection to specific tissue sites enhances local skin $\mathrm{T}_{\mathrm{RM}}$ cell numbers and provides maximal protection against pathogen challenge, demonstrating the potency of localized $\mathrm{T}_{\mathrm{RM}}$ cell deposition as a means of pathogen control $[53,54]$. Another possibility to enhance the expansion of $\mathrm{CD}^{+} \mathrm{T}_{\mathrm{RM}}$ cells is topical application of chemokines or antigenic peptides to locally boost cellular immunity [55]. Moreover, $\mathrm{T}_{\mathrm{RM}}$ cell-mediated protection can be provoked upon adoptive cell therapy (ACT) through differentiation of the transferred cells into $\mathrm{T}_{\mathrm{RM}}$ cells via pathogen-based vaccines or targeting transcription factors that promote tissue residency $[11,56]$. Hereafter, we focus on the phenotypic and functional features of $\mathrm{CD} 8^{+} \mathrm{T}_{\mathrm{RM}}$ cell heterogeneity and how these cells can be targeted to improve immunity (summarized in Figure 1). 
widespread induction of CD69 on immune cells upon infection and inflammation makes specific targeting of $\mathrm{T}_{\mathrm{RM}}$ cells via $\mathrm{CD} 69$ challenging. It remains, however, to be determined whether $\mathrm{CD} 69$ targeting affects $\mathrm{T}_{\mathrm{RM}}$ cell expansion and function during homeostatic conditions. CD38, a glycoprotein that functions as an enzyme and receptor, is also highly expressed by $\mathrm{T}_{\mathrm{RM}}$ cells [63]. However, CD38 is expressed by many other immune cells as well. Consequently, the broad expression of CD69 and CD38 make these molecules less attractive for specific targeting of $\mathrm{T}_{\mathrm{RM}}$ cells.

\subsection{Integrins}

Integrins, such as $\mathrm{CD} 49 \mathrm{a}(\alpha 1 \beta 1)$ and $\mathrm{CD} 103(\alpha \mathrm{E} \beta 7)$, mediate tissue retention of $\mathrm{CD} 8^{+}$ $\mathrm{T}_{\mathrm{RM}}$ cells. These integrins are characterized by different functions and modes of action and may show differential expression on mouse and human $\mathrm{CD}^{+} \mathrm{T}_{\mathrm{RM}}$ cells. While CD103 is absent on liver $C D 8^{+} T_{R M}$ cells in mice, it is expressed by human hepatic $C D 8^{+} T_{R M}$ cell subsets [64]. CD103 binds E-cadherin, which is commonly expressed by epithelial cells $[65,66]$. CD103 has been associated with cytotoxic $\mathrm{CD}^{+} \mathrm{T}$ cell responses in several human pathologies, including autoinflammatory diseases and cancer $[42,67,68]$. In line with this, $\mathrm{CD}_{103^{+}} \mathrm{T}_{\mathrm{RM}}$-like cells in tumors are characterized by a cytotoxic signature and are able to secrete inflammatory cytokines [11,43]. High frequencies of tumor-infiltrating $\mathrm{CD} 103^{+} \mathrm{T}$ cells are associated with improved survival rates of patients in various solid cancers [42-44], and CD103 may directly contribute to improved immune control of these malignant diseases. The interaction of CD103 with E-cadherin on tumor cells enhances cytokine production by antitumor T cells, and targeting CD103 with blocking antibodies inhibits cytotoxicity of $\mathrm{CD}_{103^{+}} \mathrm{T}$ cells towards tumor cells [68,69]. In addition, CD103 expression by skin $\mathrm{T}_{\mathrm{RM}}$ cells appears to be required for their protection against tumors [70]. Enhancing the frequency of $\mathrm{CD}_{103^{+}} \mathrm{T}_{\mathrm{RM}}$ cells thus appears to constitute an attractive approach to combat infectious and malignant diseases. CD103 may be targeted directly via specific antibodies or by modulating TGF- $\beta$ signaling, which induces CD103 expression on T cells. Using anti-CD103 and anti-CD49a blocking antibodies, knockout mice, and intravital imaging, Reilly and colleagues showed that CD103 and CD49a differentially support adherence and motility of virus-specific $\mathrm{T}$ cells after the resolution of an influenza virus infection [71]. Moreover, enhancing CD103 expression on mucosal T cells by targeting DC-dependent activation of TGF- $\beta$ has been shown to inhibit tumor progression in a preclinical model of breast cancer [72].

CD49a, also known as very late antigen-1 (VLA-1), binds collagen within the extracellular matrix to establish the tissue residency of $\mathrm{T}_{\mathrm{RM}}$ cells $[73,74]$. Recently, Bromley and colleagues showed that $C D 49$ a supports $C D 8^{+} T_{R M}$ persistence within the skin and increases the frequency of IFN- $\gamma^{+} \mathrm{CD}^{+} \mathrm{T}_{\mathrm{RM}}$ cells following local antigen challenge [75]. This suggests that CD49a acts as a costimulatory receptor and/or regulator of CD8 ${ }^{+} T_{R M}$ cell migration to increase antigen encounter in vivo. CD49a expression further defines $\mathrm{CD}^{+} \mathrm{T}_{\mathrm{RM}}$ cells in human skin that are poised for cytotoxic function [39]. Here, CD49a ${ }^{+}$ $T_{R M}$ cells produce IFN- $\gamma$, whereas CD49a- $T_{R M}$ cells produce IL-17. In addition, CD49a ${ }^{+}$ $\mathrm{T}_{\mathrm{RM}}$ cells from healthy skin rapidly induce the expression of the effector molecules perforin and granzyme $B$ when stimulated with IL-15, thereby promoting a strong cytotoxic response. Similar to CD103, CD49a expression on tumor-infiltrating $\mathrm{T}_{\mathrm{RM}}$ cells correlates with improved survival of cancer patients [76]. Antibody-mediated blockade of CD49a in turn impairs tumor control in a preclinical model [76], highlighting the functional importance of CD49a in tumor immunity. The expression of CD49a and CD103 can be induced by different cytokines, which could provide opportunities to modulate the expression of these adhesion molecules and the corresponding functional subsets of $\mathrm{T}_{\mathrm{RM}}$ cells by cytokine therapies [77]. In addition to CD49a and CD103, CD8 ${ }^{+} \mathrm{T}_{\mathrm{RM}}$ cells can upregulate LFA-1, a heterodimer composed of two members of the integrin family: $\alpha \mathrm{L}$ (CD11a) and $\beta 2$ (CD18). Using intra-vital imaging, it was found that $C D 8^{+} \mathrm{T}_{\mathrm{RM}}$ cells patrolling in the hepatic sinusoids are dependent on LFA-1-ICAM-1 interactions [78]. 


\subsection{Inhibitory Receptors}

Following activation, both circulating and $\mathrm{T}_{\mathrm{RM}}$ cells (transiently) express inhibitory receptors, such as PD-1, CTLA-4, and LAG-3 (CD223), which serve as immune checkpoints by dampening further $\mathrm{T}$ cell activation. The expression of these inhibitory molecules is associated with $\mathrm{CD}^{+} \mathrm{T}$ cell exhaustion, and consequently, many different immune-therapeutics target inhibitory immune checkpoints to improve cancer immunotherapy [79]. Evidently, during chronic viral infection, $\mathrm{T}_{\mathrm{RM}}$ cells express $\mathrm{PD}-1$ along with other exhaustion-associated molecules such as LAG-3 [80-82]. However, even in the absence of persistent antigen triggering, $\mathrm{T}_{\mathrm{RM}}$ cells express a wide variety of inhibitory receptors $[6,83]$.

In non-small cell lung carcinoma, $\mathrm{CD} 103^{+} \mathrm{CD} 8^{+} \mathrm{T}$ cells co-express $\mathrm{CD} 49 \mathrm{a}$ and $\mathrm{CD} 69$ and display a molecular profile characterized by the expression of PD-1 and the ectonucleotidase CD39 [84]. Genes involved in T cell exhaustion, including BTLA, LAG-3, and TIGIT, were more strongly expressed in $\mathrm{CD} 8^{+} \mathrm{T}_{\mathrm{RM}}$ cells than in $\mathrm{KLRG} 1^{+}$tumor-infiltrating lymphocyte (TIL) subsets. The co-expression of CD39 together with CD103 has been reported to identify tumor-reactive $\mathrm{CD} 8^{+} \mathrm{T}$ cells in solid human tumors [85]. Here, prolonged T cell receptor (TCR)stimulation in the presence of TGF- $\beta$ was necessary for the co-expression of $\mathrm{CD} 103$ and $\mathrm{CD} 39$ on $\mathrm{CD} 8{ }^{+} \mathrm{T}$ cells. $\mathrm{CD} 39^{+} \mathrm{CD} 8^{+} \mathrm{T}$ cells display divergent functional capacities and increased PD-1 expression, and are characterized by reduced expression of inflammatory cytokines (IFN- $\gamma$ and IL-2) and cytotoxic mediators (perforin and granzyme B) [86]. In addition, $\mathrm{CD} 39^{+} \mathrm{CD}^{+}$TILs exhibited suppressive function in vitro. Modulation of CD39 could provide a promising strategy to restore the suppressive CD8 ${ }^{+}$ $\mathrm{T}_{\mathrm{RM}}$ cells in these settings, as compounds inhibiting CD39-related ATPases can improve $\mathrm{CD}^{2} 9^{+} \mathrm{CD} 8^{+} \mathrm{T}$ cell effector function ex vivo [86].

Besides circulating $\mathrm{T}$ cells, $\mathrm{CD} 8^{+} \mathrm{T}_{\mathrm{RM}}$ cells also play an important role in the efficacy of PD-1/PD-L1 checkpoint blockade. Upon PD-1 blockade, CD103 ${ }^{+} \mathrm{CD} 8^{+} \mathrm{T}_{\mathrm{RM}}$ cells accumulate in tumors of therapy-responding lung cancer patients, and these cells display enhanced proliferation and cytotoxicity toward cancer cells [84]. In non-small cell lung carcinoma, tumor-specific CD $103^{+} \mathrm{CD}^{+}$TILs, expressing PD-1 and Tim-3, constitute a highly activated subpopulation and represent a prognostic factor for survival [42]. In addition to increasing the proliferation of responding T cells, the PD-L1 blockade also enhances IFN- $\gamma$ and TNF production by antigen-specific CD $8^{+} \mathrm{T}_{\mathrm{RM}}$ cells [87]. Moreover, the PD-L1 blockade induces selective expansion of tumor-infiltrating $\mathrm{CD} 4^{+}$and $\mathrm{CD} 8^{+} \mathrm{T}$ cell subsets. These subsets co-express both activating (ICOS) and inhibitory (LAG-3 and PD-1) molecules [88], and co-targeting of these molecules further improve the efficacy of the PD-1 blockade, thus demonstrating the synergistic effect of combined immunotherapies. Similarly, a combined blockade of PD-1 and LAG-3 can enhance the frequencies and functionality of virus-specific $\mathrm{CD} 8^{+} \mathrm{T}_{\mathrm{RM}}$ cells, thereby reducing disease severity following herpes simplex virus infection [89].

Although the upregulation of PD-1 in cancer and chronic infection is associated with T cell exhaustion, the physiological role of PD-1 is not negative by definition. For example, $\mathrm{T}_{\mathrm{RM}}$ cells mediate immune homeostasis in the human pancreas through the PD-1/PD-L1 pathway [90]. In addition, the expression of inhibitory receptors, including PD-1 and Tim-3, may prevent $\mathrm{T}_{\mathrm{RM}}$-mediated immunopathology in chronic inflammatory diseases [91]. In the human brain, $\mathrm{CD} 8^{+} \mathrm{T}_{\mathrm{RM}}$ cells expressing PD-1 provide protection against neurotropic virus reactivation [92]. Moreover, subsets of PD- $1^{+} \mathrm{T}$ cells possess a self-renewal capacity, and this particular population responds well to PD-1 blockade, indicating functional heterogeneity within the PD-1 ${ }^{+} \mathrm{T}$ cell pool.

Another cell surface molecule that can be expressed by CD8 ${ }^{+} \mathrm{T}_{\mathrm{RM}}$ cells is CTLA- 4 (CD152), a receptor that mediates inhibitory signals, by counteracting co-stimulation provided via CD28 by competing with CD28 for binding the shared ligands CD80/CD86 [93,94], or by actively removing these ligands via internalization for degradation [95]. Blocking CTLA-4 is thought to promote the priming of $\mathrm{CD} 8^{+} \mathrm{T}$ cells $[96,97]$. Targeting of CTLA-4 during priming indeed induces a circulating $\mathrm{CD} 8^{+} \mathrm{T}_{\mathrm{EM}}$ phenotype but also results in increased $\mathrm{CD}^{+} \mathrm{T}_{\mathrm{RM}}$ cells, leading to enhanced protection in subcutaneous tumor models [31]. 
The therapeutic effect of targeting inhibitory receptors may be further potentiated by cytokines. Tumor-derived IL-33 increases the number and function of CD103 ${ }^{+} \mathrm{CD} 8^{+}$ TILs, and a combination of IL-33 with the CTLA-4 and PD-1 immune checkpoint blockades synergistically prolonged the survival of tumor-bearing mice [98]. Finally, targeting the inhibitory receptor NKG2A may be of interest, since this molecule is expressed on tumorinfiltrating $\mathrm{NKG} \mathrm{A}^{+} \mathrm{CD}^{+} \mathrm{T}_{\mathrm{RM}}$ cells and the blockade of NKG2A potentiates $\mathrm{CD} 8^{+} \mathrm{T}$ cell immunity when combined with cancer vaccines and PD-1 blockade $[99,100]$.

\subsection{Costimulatory Receptors}

Besides inhibitory receptors, $\mathrm{CD}^{+} \mathrm{T}_{\mathrm{RM}}$ cells can express various costimulatory molecules on their cell surface, which play a key role in regulating immune responses. Most co-signaling molecules are members of the immunoglobulin superfamily (e.g., CD28 and ICOS) and the tumor necrosis factor receptor (TNFR) superfamily [101]. The costimulatory members of the TNFR superfamily, including 4-1BB (CD137), OX40 (CD134), CD27, and glucocorticoid-induced TNFR-related protein (GITR, CD357), are of interest in this respect due to their targetability using agonistic antibodies.

4-1BB regulates effector $\mathrm{CD}^{+} \mathrm{T}$ cell accumulation in the lungs through a TRAF1-, mTOR-, and antigen-dependent mechanism to enhance $T_{\mathrm{RM}}$ cell formation during respiratory influenza virus infection [102]. Combining 4-1BB agonism with the PD-L1 blockade could increase tumor-infiltrating $\mathrm{CD}_{103}{ }^{+} \mathrm{CD}^{+} \mathrm{T}_{\mathrm{RM}}$ cells, thereby enhancing tumor regression [103]. Moreover, targeting OX40 promotes lung-resident memory CD8 ${ }^{+} \mathrm{T}$ cell populations that protect against respiratory poxvirus infection [104]. The targeting of GITR by an agonistic antibody in patients with advanced cancer and in mice with advanced tumors demonstrated that GITR agonism promotes effector $\mathrm{T}$ cell functions and hampers suppression by circulating and intra-tumoral regulatory T cells [105]. GITR signaling can also advance $T_{\mathrm{RM}}$ cell formation during respiratory infection with influenza virus [106,107].

Costimulatory molecules expressed by most $\mathrm{CD}^{+} \mathrm{T}_{\mathrm{RM}}$ cell subsets are CD27 and CD28, and in non-small cell carcinoma, the CD69 ${ }^{+}$CD8 ${ }^{+}$TILs express CD27 and CD28 [108]. Agonistic CD28 stimulation ex vivo boosted TNF production by CD69 ${ }^{+} \mathrm{CD}^{+}$TILs, while the addition of CD27 costimulation further enhanced TNF and/or IFN- $\gamma$ production. These data suggest that agonistic stimulation of costimulatory receptors may improve the therapeutic efficacy of cancer immunotherapy by targeting $\mathrm{T}_{\mathrm{RM}}$ cell populations and by enhancing their expansion and/or cytokine production.

\subsection{Chemokines and Chemokine Receptors}

Chemokines control the migration of a wide variety of cell types, including $\mathrm{CD}^{+} \mathrm{T}$ cells. $\mathrm{CD}^{+} \mathrm{T}_{\mathrm{RM}}$ cells can express many different chemokine receptors, such as CXCR3, CXCR5, and CXCR6. CXCR3 mediates the migratory capacities of T cells into tissues during $\mathrm{T}_{\mathrm{RM}}$ cell development but is also directly involved in the differentiation of $\mathrm{CD} 8^{+} \mathrm{T}$ cells in response to antigen $[109,110]$. In addition, regulatory $\mathrm{T}$ cells are specifically recruited to local inflammatory sites via the chemokine receptor CXCR3 and promote the generation of $\mathrm{CD}^{+} \mathrm{T}_{\mathrm{RM}}$ cells via TGF- $\beta$ in the microenvironment [111]. During chronic lymphocytic choriomeningitis virus (LCMV) infection, virus-specific resident $\mathrm{CD}^{+} \mathrm{T}$ cells in lymphoid tissues acquire a PD- $1^{+} \mathrm{TCF} 1^{+} \mathrm{CXCR} 5^{+}$Tim- $3^{-}$stem-like phenotype [112]. These cells proliferate and give rise to the more terminally differentiated PD $-1^{+} \mathrm{CXCR} 5^{-} \mathrm{Tim}-3^{+} \mathrm{CD} 8^{+} \mathrm{T}$ cells Both subsets were found to have limited recirculation capacity as shown by parabiosis experiments. In the lungs, CXCR6 regulates the localization of $\mathrm{CD} 8^{+} \mathrm{T}_{\mathrm{RM}}$ cells to the airways [113]. Interstitial-resident memory $\mathrm{CD}^{+} \mathrm{T}$ cells sustain frontline epithelial memory in the lungs. This process is driven by CXCR6 that is expressed uniquely on $\mathrm{T}_{\mathrm{RM}}$ cells, but not $\mathrm{T}_{\mathrm{EM}}$ cells [37]. In the liver, CXCR6 is essential for $\mathrm{T}_{\mathrm{RM}}$ cell development and maintenance by binding CXCL16 secreted by liver endothelial cells. Glycolipid-peptide vaccination induces liver-resident memory $\mathrm{CD}^{+} \mathrm{T}$ cells that protect against rodent malaria [114] Vaccination-induced intrahepatic malaria-specific CD8 ${ }^{+} \mathrm{T}_{\mathrm{RM}}$ cells express CXCR6 and CD101, and these cells can be numerically increased via vaccine boosting. Topical applica- 
tion of chemokines can be used as a therapeutic strategy to direct tissue-specific $\mathrm{T}_{\mathrm{RM}}$ cell formation using a prime-pull approach. In this approach, a systemic $\mathrm{T}$ cell response is first elicited by parenteral vaccination, followed by recruitment of activated virus-specific $\mathrm{T}$ cells into the tissue by a single topical application of chemokines [115]. Here, the ligands of CXCR3, CXCL9 and CXCL10, were topically applied and mediated T cell recruitment and $\mathrm{T}_{\mathrm{RM}}$ cell formation in the skin and female reproductive tract (FRT) $[6,115]$. Thus, protective $\mathrm{T}_{\mathrm{RM}}$ cell population formation can be induced locally by targeted application of chemokines to direct $\mathrm{T}$ cell migration and differentiation. The development of agonistic and antagonistic small molecules targeting chemokine receptors may provide additional means to selectively regulate $\mathrm{T}$ cell migration and ultimately $\mathrm{T}_{\mathrm{RM}}$ cell lodgment $[116,117]$.

\subsection{Cytokines and Cytokine Receptors}

Cytokines play an important role in the differentiation and maintenance of $C D 8^{+} T_{R M}$ cells. TGF- $\beta$ induces the expression of the integrin CD103 on $T_{R M}$ cells, which allows for retention of $T_{R M}$ cells in epithelial tissues, possibly through the interaction with $E$ cadherin on epithelial cells $[6,118] . \mathrm{T}_{\mathrm{RM}}$ cells in various mucosal tissues require TGF- $\beta$ for their maintenance $[6,118,119]$, and competition for active TGF- $\beta$ allows for selective retention of antigen-specific $\mathrm{T}_{\mathrm{RM}}$ cells in the epidermal niche [120]. Comparative analysis revealed a role for TGF- $\beta$ in shaping the residency-related transcriptional signature in $\mathrm{CD} 8^{+}$ $T_{R M}$ cells [121]. In this context, TGF- $\beta$ signaling in $T_{R M}$ cells can be further modulated via external signals. Sensing of ATP via P2RX7 promotes $C D 8^{+} T_{R M}$ cell generation by enhancing their sensitivity to TGF- $\beta$ [122]. Moreover, monocyte-produced IL-10 induces the release of surface-bound TGF- $\beta$, which in turn induces CD103 upregulation on T cells. IL-10-mediated TGF- $\beta$ signaling may therefore have a critical role in the generation of $\mathrm{T}_{\mathrm{RM}}$ cells following vaccination [123]. TGF- $\beta$ is dispensable in the formation of $T_{R M}$ cells at nonmucosal sites. Consequently, targeting of TGF- $\beta$ signaling could constitute an attractive approach to specifically modulate $\mathrm{T}_{\mathrm{RM}}$ cell formation and maintenance at mucosal sites. In line with this, a blockade of TGF- $\beta$ decreases the induction of $\mathrm{T}_{\mathrm{RM}}$ cells after mucosal vaccine immunization [124].

Similar to their circulating counterparts, $\mathrm{T}_{\mathrm{RM}}$ cells in the skin, lungs, liver, salivary glands, and kidneys require IL-15 for their maintenance $[12,125,126]$. In the skin, IL-15 and IL-7 produced by hair follicles maintain $\mathrm{T}_{\mathrm{RM}}$ cells in the vicinity of these structures [127], which corresponds to the expression of CD122 (IL-15/2R $\beta$ ) and CD127 (IL7R $\alpha$ ) on these $\mathrm{T}_{\mathrm{RM}}$ cells. Moreover, IL-15 complexes induce the migration of resting memory CD8 ${ }^{+} \mathrm{T}$ cells into mucosal tissues and enhance the establishment of $\mathrm{T}_{\mathrm{RM}}$ cells within these tissues [128]. However, IL-15 may not be essential for $T_{R M}$ cells in all tissues, as pathogen-specific $\mathrm{T}_{\mathrm{RM}}$ cell populations in the pancreas, female reproductive tract, and small intestine are maintained independently of IL-15 [125]. Thus, given its role in both lodgment and maintenance of $\mathrm{T}_{\mathrm{RM}}$ cells, targeting IL-15 may improve the establishment of protective resident populations at certain tissue sites.

\subsection{Transcription Factors}

The differentiation of naïve $\mathrm{CD} 8^{+} \mathrm{T}$ cells into different memory $\mathrm{CD} 8^{+} \mathrm{T}$ cell subsets constitutes a tightly regulated process under the control of multiple transcription factors. These transcription factors in part integrate extracellular signals and thereby provide insight into the signals that promote $\mathrm{T}$ cell residency in non-lymphoid sites. The transcription factors Hobit and Blimp-1 instruct a tissue-residency program that allows for the long-term retention and maintenance of $T_{R M}$ cells within peripheral tissues [17]. The expression of the transcription factor Hobit can be induced by IL-15 signaling in a T-bet-dependent manner, which may thereby shape the transcriptional profile of $\mathrm{T}_{\mathrm{RM}}$ cells. Other transcription factors implicated in $\mathrm{T}_{\mathrm{RM}}$ cell development and maintenance include Runx3, Notch, Bhlhe40, AhR, and Nur77 [11,15,16,129,130]. Transcriptional profiling has revealed transcription factors that identify functionally distinct $\mathrm{T}_{\mathrm{RM}}$ cell subsets. Blimp-1 and Id3 expression delineate distinct tissue-resident $T$ cell subsets in the small intestine, where Id $3^{\text {hi }}$ Blimp- $1^{\text {lo }} T_{R M}$ 
cells exhibit heightened multifunctionality and memory potential [34]. While transcription factors are notoriously difficult to target for therapeutic purposes, preclinical studies have assessed their role in $\mathrm{T}_{\mathrm{RM}}$ cell formation and functionality using transgenic systems. In a study by Milner et al., the overexpression of Runx3 in adoptively transferred CD8 ${ }^{+} \mathrm{T}$ cells inhibited tumor outgrowth and prolonged survival of mice in a preclinical model of melanoma [11]. In contrast, $\mathrm{CD} 8^{+} \mathrm{T}$ cells lacking Run 33 expression did not accumulate in the tumor microenvironment, resulting in uncontrolled tumor growth and reduced survival. Thus, targeting transcription factors to promote tissue residency could be used to enhance vaccine efficacy or adoptive cell therapy treatments that target cancer.

Certain transcription factors regulating $\mathrm{T}_{\mathrm{RM}}$ cell development directly integrate extracellular signals. For instance, the activity of AhR, a crucial regulator in maintaining intraepithelial lymphocyte numbers in both the skin and the intestine, can be induced by dietary components, such as those present in cruciferous vegetables, providing a mechanistic link between dietary compounds and the intestinal immune system [131]. Moreover, the transcription factor Notch, which controls the maintenance of $T_{R M}$ cells in the lungs [16], is directly induced by corresponding ligands on neighboring cells. In contrast, the expression of the transcription factor Bhlhe40, which is important for the mitochondrial fitness of $T_{R M}$ cells (as will be discussed hereafter) can be inhibited by local PD-1 signaling [15]. Consequently, the activity of multiple transcription factors important for $\mathrm{T}_{\mathrm{RM}}$ cell development and function can be modulated directly via extracellular signals. Local and temporal provision of these signals may aid future immunization strategies aiming to induce protective $\mathrm{T}_{\mathrm{RM}}$ cell populations. Furthermore, the advent of transgenic $\mathrm{T}$ cell therapies may provide a platform to equip adoptively transferred $\mathrm{T}$ cells with a transcriptional program favoring tissue residency and persistence.

\subsection{Metabolic Reprogramming}

$\mathrm{T}_{\mathrm{RM}}$ cells undergo tissue-specific metabolic adaptations to persist at tissue sites with restricted nutrient availability. Given their localization within the tissue, $T_{R M}$ cells differ in their access to nutrients and oxygen in comparison to their circulating counterparts. $\mathrm{T}_{\mathrm{RM}}$ cells in the liver specifically upregulate the hypoxia-inducible transcription factor HIF-2 $\alpha$ [132], suggesting that $T_{R M}$ cells primarily reside within hypoxic regions of the liver. Effector responses and survival of liver $\mathrm{T}_{\mathrm{RM}}$ cells further depend on HIF-2 $\alpha$, indicating a direct link between metabolic conditions, functionality and maintenance of $T_{R M}$ cells. In the skin, $\mathrm{T}_{\mathrm{RM}}$ cells utilize mitochondrial $\beta$-oxidation of exogenous FFA taken up via fatty acid binding protein (FABP) 4 and 5 for their survival and functionality [26]. $\mathrm{T}_{\mathrm{RM}}$ cells at other tissue sites may also rely on fatty acid oxidation but express different FABP isoforms, with FABP1 supporting the establishment of $T_{R M}$ cells in the liver [27]. Similarly, $\mathrm{T}_{\mathrm{RM}}$ cells in gastric adenocarcinoma rely on fatty acid oxidation for their survival and may compete with tumor cells for the uptake of fatty acids [133]. Circulating $\mathrm{CD}^{+} \mathrm{T}_{\mathrm{CM}}$ cells also depend in part on mitochondrial fatty acid oxidation for cellular metabolism. However, rather than acquiring exogenous fatty acids like $\mathrm{T}_{\mathrm{RM}}$ cells, $\mathrm{T}_{\mathrm{CM}}$ cells appear to synthesize fatty acids from exogenous glucose and glycerol to support fatty acid oxidation and cellular longevity [134-136]. Consequently, targeting fatty acid uptake and oxidation might represent an attractive approach to specifically modulate $T_{R M}$ cell longevity and functionality. The mitochondrial metabolism of $\mathrm{T}_{\mathrm{RM}}$ cells is, in part, regulated by the transcription factor Bhlhe40, which supports the TCA cycle activity and oxidative phosphorylation in $\mathrm{T}_{\mathrm{RM}}$ cells [15]. The efficacy of the PD-L1 blockade in reinvigorating tumor-infiltrating $\mathrm{T}_{\mathrm{RM}}$ cells depends on Bhlhe40, and Bhlhe40 might therefore constitute a nexus between immunomodulatory signals, metabolism, and functionality of tissue-resident T cell populations. Interestingly, Lin et al. found that the PD-L1 blockade promoted FABP4/5 expression, fatty acid uptake, and survival of tumor-infiltrating $\mathrm{T}_{\mathrm{RM}}$ cells in gastric cancer [133]. The induction of metabolic changes in tissue-resident $\mathrm{T}$ cell populations may therefore contribute to the effectiveness of an immune checkpoint blockade. Given that $\mathrm{T}_{\mathrm{RM}}$ cells in many tissues express high amounts of inhibitory receptors 
(including PD-1, Tim-3, and CTLA-4) $[6,16,43,137]$, an immune checkpoint blockade may allow for the manipulation of both functionality and metabolic fitness of $\mathrm{T}_{\mathrm{RM}}$ cells. Direct targeting of metabolic pathways sustaining $\mathrm{T}_{\mathrm{RM}}$ cells could be another way to regulate $\mathrm{T}_{\mathrm{RM}}$ cell maintenance. The pharmacological inhibition of mitochondrial $\beta$-oxidation in vivo decreases the maintenance and survival of $\mathrm{T}_{\mathrm{RM}}$ cells in the skin [26]. The external modulation of $\mathrm{T}_{\mathrm{RM}}$ cell metabolism could thus be employed to either increase or decrease local $\mathrm{T}_{\mathrm{RM}}$ cell populations. As $\mathrm{T}_{\mathrm{RM}}$ cells have been implicated in the pathogenesis of various inflammatory diseases such as psoriasis in the skin [138], targeting the specific metabolic requirements of these cells might thus also constitute a potential therapeutic approach to treat auto-inflammatory disorders.

\section{Conclusions}

The tissue environment, cellular interaction partners, local cytokines and chemokines, as well as antigen triggering play roles in the development of $C D 8^{+} T_{R M}$ cells and shape the phenotype of these cells. Consequently, $\mathrm{CD} 8^{+} \mathrm{T}_{\mathrm{RM}}$ cells arising at different sites and responding to different infections are characterized by diverse phenotypes. This phenotypic heterogeneity is exemplified by the expression of various cell surface molecules, transcription factors, and diverse metabolic and signaling pathways. The heterogeneous nature of $C D 8^{+} T_{R M}$ cells may allow for the specific targeting of $T_{R M}$ cell subsets in selected organs for immunotherapy. Thus far, memory $\mathrm{CD}^{+} \mathrm{T}$ cell subsets are mostly nonspecifically targeted, while targeting of specific $\mathrm{CD}^{+} \mathrm{T}_{\mathrm{RM}}$ cell subsets may be more beneficial. However, this remains challenging. A better understanding of the molecular determinants of $\mathrm{CD}^{+} \mathrm{T}_{\mathrm{RM}}$ cell heterogeneity is therefore crucial to improve the design of vaccines and immunotherapies aiming to harness the protective capacity of $T_{R M}$ cell subsets.

Author Contributions: Writing—Original draft: E.T.I.v.d.G., F.M.B.; Writing—Review \& Editing: E.T.I.v.d.G., F.M.B., R.A.; Supervision: R.A.; Funding Acquisition: E.T.I.v.d.G. and R.A. All authors have read and agreed to the published version of the manuscript.

Funding: This work was supported by a BWplus grant from the LUMC and the graduate program of the Dutch Research Council (awarded to EvdG) and by a Dutch Cancer Society grant (KWF UL2015-7817 awarded to RA).

Institutional Review Board Statement: Not applicable.

Informed Consent Statement: Not applicable.

Data Availability Statement: Not applicable.

Conflicts of Interest: The authors declare no conflict of interest.

\section{References}

1. Arens, R.; Schoenberger, S.P. Plasticity in programming of effector and memory CD8 T-cell formation. Immunol. Rev. 2010, 235, 190-205. [CrossRef]

2. Sallusto, F.; Geginat, J.; Lanzavecchia, A. Central memory and effector memory T cell subsets: Function, generation, and maintenance. Ann. Rev. Immunol. 2004, 22, 745-763. [CrossRef] [PubMed]

3. Schenkel, J.M.; Fraser, K.A.; Masopust, D. Cutting edge: Resident memory CD8 T cells occupy frontline niches in secondary lymphoid organs. J. Immunol. 2014, 192, 2961-2964. [CrossRef] [PubMed]

4. Masopust, D.; Choo, D.; Vezys, V.; Wherry, E.J.; Duraiswamy, J.; Akondy, R.; Wang, J.; Casey, K.A.; Barber, D.L.; Kawamura, K.S.; et al. Dynamic T cell migration program provides resident memory within intestinal epithelium. J. Exp. Med. 2010, 207, 553-564. [CrossRef] [PubMed]

5. Gebhardt, T.; Wakim, L.M.; Eidsmo, L.; Reading, P.C.; Heath, W.R.; Carbone, F.R. Memory T cells in nonlymphoid tissue that provide enhanced local immunity during infection with herpes simplex virus. Nat. Immunol. 2009, 10, 524-530. [CrossRef]

6. Mackay, L.K.; Rahimpour, A.; Ma, J.Z.; Collins, N.; Stock, A.T.; Hafon, M.L.; Vega-Ramos, J.; Lauzurica, P.; Mueller, S.N.; Stefanovic, T.; et al. The developmental pathway for CD103(+)CD8+ tissue-resident memory T cells of skin. Nat. Immunol. 2013, 14, 1294-1301. [CrossRef] [PubMed]

7. Casey, K.A.; Fraser, K.A.; Schenkel, J.M.; Moran, A.; Abt, M.C.; Beura, L.K.; Lucas, P.J.; Artis, D.; Wherry, E.J.; Hogquist, K.; et al. Antigen-independent differentiation and maintenance of effector-like resident memory T cells in tissues. J. Immunol. 2012, 188, 4866-4875. [CrossRef] 
8. Schenkel, J.M.; Fraser, K.A.; Beura, L.K.; Pauken, K.E.; Vezys, V.; Masopust, D. T cell memory. Resident memory CD8 T cells trigger protective innate and adaptive immune responses. Science 2014, 346, 98-101. [CrossRef]

9. Rosato, P.C.; Beura, L.K.; Masopust, D. Tissue resident memory T cells and viral immunity. Curr. Opin. Virol. 2017, 22, 44-50. [CrossRef]

10. Herndler-Brandstetter, D.; Ishigame, H.; Shinnakasu, R.; Plajer, V.; Stecher, C.; Zhao, J.; Lietzenmayer, M.; Kroehling, L.; Takumi, A.; Kometani, K.; et al. KLRG1+ Effector CD8+ T Cells lose KLRG1, differentiate into all memory T cell lineages, and convey enhanced protective immunity. Immunity 2018, 48, 716-729.e718. [CrossRef]

11. Milner, J.J.; Toma, C.; Yu, B.; Zhang, K.; Omilusik, K.; Phan, A.T.; Wang, D.; Getzler, A.J.; Nguyen, T.; Crotty, S.; et al. Runx3 programs CD8(+) T cell residency in non-lymphoid tissues and tumours. Nature 2017, 552, 253-257. [CrossRef]

12. Mackay, L.K.; Wynne-Jones, E.; Freestone, D.; Pellicci, D.G.; Mielke, L.A.; Newman, D.M.; Braun, A.; Masson, F.; Kallies, A.; Belz, G.T.; et al. T-box transcription factors combine with the cytokines TGF-beta and IL-15 to control tissue-resident memory T cell fate. Immunity 2015, 43, 1101-1111. [CrossRef] [PubMed]

13. Bergsbaken, T.; Bevan, M.J. Proinflammatory microenvironments within the intestine regulate the differentiation of tissue-resident CD8(+) T cells responding to infection. Nat. Immunol. 2015, 16, 406-414. [CrossRef] [PubMed]

14. Bergsbaken, T.; Bevan, M.J.; Fink, P.J. Local inflammatory cues regulate differentiation and persistence of CD8+ tissue-resident memory T cells. Cell Rep. 2017, 19, 114-124. [CrossRef] [PubMed]

15. Li, C.; Zhu, B.; Son, Y.M.; Wang, Z.; Jiang, L.; Xiang, M.; Ye, Z.; Beckermann, K.E.; Wu, Y.; Jenkins, J.W.; et al. The transcription factor Bhlhe40 programs mitochondrial regulation of resident CD8+ T cell fitness and functionality. Immunity 2019, 51, 491507.e497. [CrossRef]

16. Hombrink, P.; Helbig, C.; Backer, R.A.; Piet, B.; Oja, A.E.; Stark, R.; Brasser, G.; Jongejan, A.; Jonkers, R.E.; Nota, B.; et al. Programs for the persistence, vigilance and control of human CD8+ lung-resident memory T cells. Nat. Immunol. 2016, 17, 1467-1478. [CrossRef]

17. Mackay, L.K.; Minnich, M.; Kragten, N.A.; Liao, Y.; Nota, B.; Seillet, C.; Zaid, A.; Man, K.; Preston, S.; Freestone, D.; et al. Hobit and Blimp1 instruct a universal transcriptional program of tissue residency in lymphocytes. Science 2016, 352, 459-463. [CrossRef]

18. Behr, F.M.; Kragten, N.A.M.; Wesselink, T.H.; Nota, B.; Van Lier, R.A.W.; Amsen, D.; Stark, R.; Hombrink, P.; Van Gisbergen, K. Blimp-1 Rather Than Hobit Drives the Formation of Tissue-Resident Memory CD8(+) T Cells in the Lungs. Front. Immunol. 2019, 10, 400. [CrossRef]

19. Fernandez-Ruiz, D.; Ng, W.Y.; Holz, L.E.; Ma, J.Z.; Zaid, A.; Wong, Y.C.; Lau, L.S.; Mollard, V.; Cozijnsen, A.; Collins, N.; et al. Liver-resident memory CD8+ T cells form a front-line defense against malaria liver-stage infection. Immunity 2016, 45, 889-902. [CrossRef]

20. Steinert, E.M.; Schenkel, J.M.; Fraser, K.A.; Beura, L.K.; Manlove, L.S.; Igyarto, B.Z.; Southern, P.J.; Masopust, D. Quantifying memory CD8 T cells reveals regionalization of immunosurveillance. Cell 2015, 161, 737-749. [CrossRef]

21. Boldison, J.; Chu, C.J.; Copland, D.A.; Lait, P.J.; Khera, T.K.; Dick, A.D.; Nicholson, L.B. Tissue-resident exhausted effector memory CD8+ T cells accumulate in the retina during chronic experimental autoimmune uveoretinitis. J. Immunol. 2014, 192, 4541-4550. [CrossRef] [PubMed]

22. Morris, M.A.; Gibb, D.R.; Picard, F.; Brinkmann, V.; Straume, M.; Ley, K. Transient T cell accumulation in lymph nodes and sustained lymphopenia in mice treated with FTY720. Eur. J. Immunol. 2005, 35, 3570-3580. [CrossRef] [PubMed]

23. Snyder, M.E.; Finlayson, M.O.; Connors, T.J.; Dogra, P.; Senda, T.; Bush, E.; Carpenter, D.; Marboe, C.; Benvenuto, L.; Shah, L.; et al. Generation and persistence of human tissue-resident memory T cells in lung transplantation. Sci. Immunol. 2019,4 , eaav5581. [CrossRef]

24. Bartolomé-Casado, R.; Landsverk, O.J.B.; Chauhan, S.K.; Richter, L.; Phung, D.; Greiff, V.; Risnes, L.F.; Yao, Y.; Neumann, R.S.; Yaqub, S.; et al. Resident memory CD8 T cells persist for years in human small intestine. J. Exp. Med. 2019, 216, $2412-2426$. [CrossRef] [PubMed]

25. Stark, R.; Wesselink, T.H.; Behr, F.M.; Kragten, N.A.M.; Arens, R.; Koch-Nolte, F.; Van Gisbergen, K.; Van Lier, R.A.W. T (RM) maintenance is regulated by tissue damage via P2RX7. Sci. Immunol. 2018, 3, eaau1022. [CrossRef]

26. Pan, Y.; Tian, T.; Park, C.O.; Lofftus, S.Y.; Mei, S.; Liu, X.; Luo, C.; O’Malley, J.T.; Gehad, A.; Teague, J.E.; et al. Survival of tissue-resident memory $T$ cells requires exogenous lipid uptake and metabolism. Nature 2017, 543, 252-256. [CrossRef]

27. Frizzell, H.; Fonseca, R.; Christo, S.N.; Evrard, M.; Cruz-Gomez, S.; Zanluqui, N.G.; Von Scheidt, B.; Freestone, D.; Park, S.L.; McWilliam, H.E.G.; et al. Organ-specific isoform selection of fatty acid-binding proteins in tissue-resident lymphocytes. Sci. Immunol. 2020, 5, eaay9283. [CrossRef]

28. Park, S.L.; Zaid, A.; Hor, J.L.; Christo, S.N.; Prier, J.E.; Davies, B.; Alexandre, Y.O.; Gregory, J.L.; Russell, T.A.; Gebhardt, T.; et al. Local proliferation maintains a stable pool of tissue-resident memory T cells after antiviral recall responses. Nat. Immunol. 2018, 19, 183-191. [CrossRef]

29. Behr, F.M.; Parga-Vidal, L.; Kragten, N.A.M.; Van Dam, T.J.P.; Wesselink, T.H.; Sheridan, B.S.; Arens, R.; Van Lier, R.A.W.; Stark, R.; Van Gisbergen, K. Tissue-resident memory CD8(+) T cells shape local and systemic secondary T cell responses. Nat. Immunol. 2020, 21, 1070-1081. [CrossRef]

30. Beura, L.K.; Mitchell, J.S.; Thompson, E.A.; Schenkel, J.M.; Mohammed, J.; Wijeyesinghe, S.; Fonseca, R.; Burbach, B.J.; Hickman, H.D.; Vezys, V.; et al. Intravital mucosal imaging of CD8(+) resident memory T cells shows tissue-autonomous recall responses that amplify secondary memory. Nat. Immunol. 2018, 19, 173-182. [CrossRef] 
31. Van der Gracht, E.T.; Schoonderwoerd, M.J.; van Duikeren, S.; Yilmaz, A.N.; Behr, F.M.; Colston, J.M.; Lee, L.N.; Yagita, H.; Van Gisbergen, K.P.; Hawinkels, L.J.; et al. Adenoviral vaccines promote protective tissue-resident memory T cell populations against cancer. J. Immunother. Cancer 2020, 8, e001133. [CrossRef] [PubMed]

32. Behr, F.M.; Beumer-Chuwonpad, A.; Kragten, N.A.M.; Wesselink, T.H.; Stark, R.; Van Gisbergen, K. Circulating memory CD8(+) T cells are limited in forming CD103(+) tissue-resident memory $\mathrm{T}$ cells at mucosal sites after reinfection. Eur. J. Immunol. 2020. [CrossRef] [PubMed]

33. Fonseca, R.; Beura, L.K.; Quarnstrom, C.F.; Ghoneim, H.E.; Fan, Y.; Zebley, C.C.; Scott, M.C.; Fares-Frederickson, N.J.; Wijeyesinghe, S.; Thompson, E.A.; et al. Developmental plasticity allows outside-in immune responses by resident memory T cells. Nat. Immunol. 2020, 21, 412-421. [CrossRef] [PubMed]

34. Milner, J.J.; Toma, C.; He, Z.; Kurd, N.S.; Nguyen, Q.P.; McDonald, B.; Quezada, L.; Widjaja, C.E.; Witherden, D.A.; Crowl, J.T.; et al. Heterogenous populations of tissue-resident CD8+ T cells are generated in response to infection and malignancy. Immunity 2020, 52, 808-824.e807. [CrossRef] [PubMed]

35. Kurd, N.S.; He, Z.; Louis, T.L.; Milner, J.J.; Omilusik, K.D.; Jin, W.; Tsai, M.S.; Widjaja, C.E.; Kanbar, J.N.; Olvera, J.G.; et al. Early precursors and molecular determinants of tissue-resident memory CD8+ T lymphocytes revealed by single-cell RNA sequencing. Sci. Immunol. 2020, 5, eaaz6894. [CrossRef]

36. Van der Gracht, E.T.I.; Beyrend, G.; Abdelaal, T.; Pardieck, I.N.; Wesselink, T.H.; Van Haften, F.J.; Van Duikeren, S.; Koning, F.; Arens, R. Memory CD8+ T cell heterogeneity is primarily driven by pathogen-specific cues and additionally shaped by the tissue environment. iScience 2021, 24, 101954. [CrossRef]

37. Takamura, S.; Kato, S.; Motozono, C.; Shimaoka, T.; Ueha, S.; Matsuo, K.; Miyauchi, K.; Masumoto, T.; Katsushima, A.; Nakayama, T.; et al. Interstitial-resident memory CD8(+) T cells sustain frontline epithelial memory in the lung. J. Exp. Med. 2019, 216, 2736-2747. [CrossRef]

38. Low, J.S.; Farsakoglu, Y.; Amezcua Vesely, M.C.; Sefik, E.; Kelly, J.B.; Harman, C.C.D.; Jackson, R.; Shyer, J.A.; Jiang, X.; Cauley, L.S.; et al. Tissue-resident memory $\mathrm{T}$ cell reactivation by diverse antigen-presenting cells imparts distinct functional responses. $J$. Exp. Med. 2020, 217, 217. [CrossRef]

39. Cheuk, S.; Schlums, H.; Gallais Sérézal, I.; Martini, E.; Chiang, S.C.; Marquardt, N.; Gibbs, A.; Detlofsson, E.; Introini, A.; Forkel, M.; et al. CD49a expression defines tissue-resident CD8(+) T cells poised for cytotoxic function in human skin. Immunity 2017, 46, 287-300. [CrossRef]

40. Kaech, S.M.; Wherry, E.J. Heterogeneity and cell-fate decisions in effector and memory CD8+ T cell differentiation during viral infection. Immunity 2007, 27, 393-405. [CrossRef]

41. Jameson, S.C.; Masopust, D. Understanding subset diversity in T cell memory. Immunity 2018, 48, 214-226. [CrossRef] [PubMed]

42. Djenidi, F.; Adam, J.; Goubar, A.; Durgeau, A.; Meurice, G.; De Montpréville, V.; Validire, P.; Besse, B.; Mami-Chouaib, F. CD8+CD103+ tumor-infiltrating lymphocytes are tumor-specific tissue-resident memory T cells and a prognostic factor for survival in lung cancer patients. J. Immunol. 2015, 194, 3475-3486. [CrossRef] [PubMed]

43. Ganesan, A.P.; Clarke, J.; Wood, O.; Garrido-Martin, E.M.; Chee, S.J.; Mellows, T.; Samaniego-Castruita, D.; Singh, D.; Seumois, G.; Alzetani, A.; et al. Tissue-resident memory features are linked to the magnitude of cytotoxic T cell responses in human lung cancer. Nat. Immunol. 2017, 18, 940-950. [CrossRef]

44. Koh, J.; Kim, S.; Kim, M.Y.; Go, H.; Jeon, Y.K.; Chung, D.H. Prognostic implications of intratumoral CD103+ tumor-infiltrating lymphocytes in pulmonary squamous cell carcinoma. Oncotarget 2017, 8, 13762-13769. [CrossRef] [PubMed]

45. Park, S.L.; Buzzai, A.; Rautela, J.; Hor, J.L.; Hochheiser, K.; Effern, M.; McBain, N.; Wagner, T.; Edwards, J.; McConville, R.; et al. Tissue-resident memory CD8(+) T cells promote melanoma-immune equilibrium in skin. Nature 2019, 565, 366-371. [CrossRef]

46. Gálvez-Cancino, F.; López, E.; Menares, E.; Díaz, X.; Flores, C.; Cáceres, P.; Hidalgo, S.; Chovar, O.; Alcántara-Hernández, M.; Borgna, V.; et al. Vaccination-induced skin-resident memory CD8+ T cells mediate strong protection against cutaneous melanoma. OncoImmunology 2018, 7, e1442163. [CrossRef]

47. Menares, E.; Gálvez-Cancino, F.; Cáceres-Morgado, P.; Ghorani, E.; López, E.; Díaz, X.; Saavedra-Almarza, J.; Figueroa, D.A.; Roa, E.; Quezada, S.A.; et al. Tissue-resident memory CD8+ T cells amplify anti-tumor immunity by triggering antigen spreading through dendritic cells. Nat. Commun. 2019, 10, 4401. [CrossRef]

48. Zens, K.D.; Chen, J.K.; Farber, D.L. Vaccine-generated lung tissue-resident memory T cells provide heterosubtypic protection to influenza infection. JCI Insight 2016, 1, e85832. [CrossRef]

49. Dumauthioz, N.; Labiano, S.; Romero, P. Tumor resident memory T cells: New players in immune surveillance and therapy. Front. Immunol. 2018, 9, 2076. [CrossRef]

50. Mackay, L.K.; Stock, A.T.; Ma, J.Z.; Jones, C.M.; Kent, S.J.; Mueller, S.N.; Heath, W.R.; Carbone, F.R.; Gebhardt, T. Long-lived epithelial immunity by tissue-resident memory T (TRM) cells in the absence of persisting local antigen presentation. Proc. Natl. Acad. Sci. USA 2012, 109, 7037-7042. [CrossRef]

51. Muschaweckh, A.; Buchholz, V.R.; Fellenzer, A.; Hessel, C.; König, P.-A.; Tao, S.; Tao, R.; Heikenwälder, M.; Busch, D.H.; Korn, T.; et al. Antigen-dependent competition shapes the local repertoire of tissue-resident memory CD8+ T cells. J. Exp. Med. 2016, 213, 3075-3086. [CrossRef] [PubMed]

52. Khan, T.N.; Mooster, J.L.; Kilgore, A.M.; Osborn, J.F.; Nolz, J.C. Local antigen in nonlymphoid tissue promotes resident memory CD8+ T cell formation during viral infection. J. Exp. Med. 2016, 213, 951-966. [CrossRef] [PubMed] 
53. Davies, B.; Prier, J.E.; Jones, C.M.; Gebhardt, T.; Carbone, F.R.; Mackay, L.K. Cutting edge: Tissue-resident memory T cells generated by multiple immunizations or localized deposition provide enhanced immunity. J. Immunol. 2017, 198, $2233-2237$. [CrossRef] [PubMed]

54. Jiang, X.; Clark, R.A.; Liu, L.; Wagers, A.J.; Fuhlbrigge, R.C.; Kupper, T.S. Skin infection generates non-migratory memory CD8+ $\mathrm{T}(\mathrm{RM})$ cells providing global skin immunity. Nature 2012, 483, 227-231. [CrossRef]

55. Hobbs, S.J.; Nolz, J.C. Targeted Expansion of tissue-resident CD8+ T cells to boost cellular immunity in the skin. Cell Rep. 2019, 29, 2990-2997.e2. [CrossRef]

56. Xin, G.; Khatun, A.; Topchyan, P.; Zander, R.; Volberding, P.J.; Chen, Y.; Shen, J.; Fu, C.; Jiang, A.; See, W.A.; et al. Pathogen-boosted adoptive cell transfer therapy induces endogenous antitumor immunity through antigen spreading. Cancer Immunol. Res. 2020, 8 , 7-18. [CrossRef]

57. Mackay, L.K.; Braun, A.; Macleod, B.L.; Collins, N.; Tebartz, C.; Bedoui, S.; Carbone, F.R.; Gebhardt, T. Cutting edge: CD69 interference with sphingosine-1-phosphate receptor function regulates peripheral T cell retention. J. Immunol. 2015, 194, 2059-2063. [CrossRef]

58. Shiow, L.R.; Rosen, D.B.; Brdicková, N.; Xu, Y.; An, J.; Lanier, L.L.; Cyster, J.G.; Matloubian, M. CD69 acts downstream of interferon-alpha/beta to inhibit S1P1 and lymphocyte egress from lymphoid organs. Nature 2006, 440, 540-544. [CrossRef]

59. Skon, C.N.; Lee, J.Y.; Anderson, K.G.; Masopust, D.; Hogquist, K.A.; Jameson, S.C. Transcriptional downregulation of S1pr1 is required for the establishment of resident memory CD8+ T cells. Nat. Immunol. 2013, 14, 1285-1293. [CrossRef]

60. Notario, L.; Redondo-Antón, J.; Alari-Pahissa, E.; Albentosa, A.; Leiva, M.; Lopez, D.; Sabio, G.; Lauzurica, P. CD69 targeting enhances anti-vaccinia virus immunity. J. Virol. 2019, 93, 00553. [CrossRef]

61. Notario, L.; Alari-Pahissa, E.; Albentosa, A.; Leiva, M.; Sabio, G.; Lauzurica, P. Anti-CD69 therapy induces rapid mobilization and high proliferation of HSPCs through S1P and mTOR. Leukemia 2018, 32, 1445-1457. [CrossRef] [PubMed]

62. Alari-Pahissa, E.; Vega-Ramos, J.; Zhang, J.G.; Castaño, A.R.; Turley, S.J.; Villadangos, J.A.; Lauzurica, P. Differential effect of CD69 targeting on bystander and antigen-specific T cell proliferation. J. Leukoc. Biol. 2012, 92, 145-158. [CrossRef] [PubMed]

63. Yang, Q.; Zhang, M.; Chen, Q.; Chen, W.; Wei, C.; Qiao, K.; Ye, T.; Deng, G.; Li, J.; Zhu, J.; et al. Cutting edge: Characterization of human tissue-resident memory $\mathrm{T}$ cells at different infection sites in patients with tuberculosis. J. Immunol. 2020, 204, 2331-2336. [CrossRef] [PubMed]

64. Stelma, F.; De Niet, A.; Sinnige, M.J.; Van Dort, K.A.; Van Gisbergen, K.; Verheij, J.; Van Leeuwen, E.M.M.; Kootstra, N.A.; Reesink, H.W. Human intrahepatic CD69 + CD8+ T cells have a tissue resident memory T cell phenotype with reduced cytolytic capacity. Sci. Rep. 2017, 7, 6172. [CrossRef]

65. Cepek, K.L.; Parker, C.M.; Madara, J.L.; Brenner, M.B. Integrin alpha E beta 7 mediates adhesion of T lymphocytes to epithelial cells. J. Immunol. 1993, 150, 3459-3470.

66. Cepek, K.L.; Shaw, S.K.; Parker, C.M.; Russell, G.J.; Morrow, J.S.; Rimm, D.L.; Brenner, M.B. Adhesion between epithelial cells and T lymphocytes mediated by E-cadherin and the $\alpha E \beta 7$ integrin. Nature 1994, 372, 190-193. [CrossRef]

67. Oshitani, N.; Watanabe, K.; Maeda, K.; Fujiwara, Y.; Higuchi, K.; Matsumoto, T.; Arakawa, T. Differential expression of homing receptor CD103 on lamina propria lymphocytes and association of CD103 with epithelial adhesion molecules in inflammatory bowel disease. Int. J. Mol. Med. 2003, 12, 715-719. [CrossRef]

68. Le Floc'h, A.; Jalil, A.; Vergnon, I.; Le Maux Chansac, B.; Lazar, V.; Bismuth, G.; Chouaib, S.; Mami-Chouaib, F. Alpha E beta 7 integrin interaction with E-cadherin promotes antitumor CTL activity by triggering lytic granule polarization and exocytosis. J. Exp. Med. 2007, 204, 559-570. [CrossRef]

69. Franciszkiewicz, K.; Le Floc'h, A.; Boutet, M.; Vergnon, I.; Schmitt, A.; Mami-Chouaib, F. CD103 or LFA-1 engagement at the immune synapse between cytotoxic $\mathrm{T}$ cells and tumor cells promotes maturation and regulates T-cell effector functions. Cancer Res. 2013, 73, 617-628. [CrossRef]

70. Malik, B.T.; Byrne, K.T.; Vella, J.L.; Zhang, P.; Shabaneh, T.B.; Steinberg, S.M.; Molodtsov, A.K.; Bowers, J.S.; Angeles, C.V.; Paulos, C.M.; et al. Resident memory T cells in skin mediate durable immunity to melanoma. Sci. Immunol. 2017, 2, eaam6346. [CrossRef]

71. Reilly, E.C.; Lambert Emo, K.; Buckley, P.M.; Reilly, N.S.; Smith, I.; Chaves, F.A.; Yang, H.; Oakes, P.W.; Topham, D.J. TRM integrins CD103 and CD49a differentially support adherence and motility after resolution of influenza virus infection. Proc. Natl. Acad. Sci. USA 2020, 117, 12306-12314. [CrossRef] [PubMed]

72. Wu, T.C.; Xu, K.; Banchereau, R.; Marches, F.; Yu, C.I.; Martinek, J.; Anguiano, E.; Pedroza-Gonzalez, A.; Snipes, G.J.; O'Shaughnessy, J.; et al. Reprogramming tumor-infiltrating dendritic cells for CD103+ CD8+ mucosal T-cell differentiation and breast cancer rejection. Cancer Immunol. Res. 2014, 2, 487-500. [CrossRef] [PubMed]

73. Roberts, A.I.; Brolin, R.E.; Ebert, E.C. Integrin alpha1beta1 (VLA-1) mediates adhesion of activated intraepithelial lymphocytes to collagen. Immunology 1999, 97, 679-685. [CrossRef] [PubMed]

74. Ray, S.J.; Franki, S.N.; Pierce, R.H.; Dimitrova, S.; Koteliansky, V.; Sprague, A.G.; Doherty, P.C.; de Fougerolles, A.R.; Topham, D.J. The collagen binding alpha1beta1 integrin VLA-1 regulates CD8 T cell-mediated immune protection against heterologous influenza infection. Immunity 2004, 20, 167-179. [CrossRef]

75. Bromley, S.K.; Akbaba, H.; Mani, V.; Mora-Buch, R.; Chasse, A.Y.; Sama, A.; Luster, A.D. CD49a Regulates Cutaneous Resident Memory CD8(+) T Cell Persistence and Response. Cell Rep. 2020, 32, 108085. [CrossRef] [PubMed] 
76. Murray, T.; Fuertes Marraco, S.A.; Baumgaertner, P.; Bordry, N.; Cagnon, L.; Donda, A.; Romero, P.; Verdeil, G.; Speiser, D.E. Very late antigen-1 marks functional tumor-resident CD8 T cells and correlates with survival of melanoma patients. Front. Immunol. 2016, 7, 573. [CrossRef] [PubMed]

77. Melssen, M.M.; Olson, W.; Wages, N.A.; Capaldo, B.J.; Mauldin, I.S.; Mahmutovic, A.; Hutchison, C.; Melief, C.J.M.; Bullock, T.N.; Engelhard, V.H.; et al. Formation and phenotypic characterization of CD49a, CD49b and CD103 expressing CD8 T cell populations in human metastatic melanoma. OncoImmunology 2018, 7, e1490855. [CrossRef] [PubMed]

78. McNamara, H.A.; Cai, Y.; Wagle, M.V.; Sontani, Y.; Roots, C.M.; Miosge, L.A.; O'Connor, J.H.; Sutton, H.J.; Ganusov, V.V.; Heath, W.R.; et al. Up-regulation of LFA-1 allows liver-resident memory T cells to patrol and remain in the hepatic sinusoids. Sci. Immunol. 2017, 2, eaaj1996. [CrossRef]

79. Gong, J.; Chehrazi-Raffle, A.; Reddi, S.; Salgia, R. Development of PD-1 and PD-L1 inhibitors as a form of cancer immunotherapy: A comprehensive review of registration trials and future considerations. J. Immunother. Cancer 2018, 6, 8. [CrossRef]

80. Barber, D.L.; Wherry, E.J.; Masopust, D.; Zhu, B.; Allison, J.P.; Sharpe, A.H.; Freeman, G.J.; Ahmed, R. Restoring function in exhausted CD8 T cells during chronic viral infection. Nature 2006, 439, 682-687. [CrossRef]

81. Gupta, P.K.; Godec, J.; Wolski, D.; Adland, E.; Yates, K.; Pauken, K.E.; Cosgrove, C.; Ledderose, C.; Junger, W.G.; Robson, S.C.; et al. CD39 Expression identifies terminally exhausted CD8+ T cells. PLoS Pathog. 2015, 11, e1005177. [CrossRef] [PubMed]

82. Blackburn, S.D.; Shin, H.; Haining, W.N.; Zou, T.; Workman, C.J.; Polley, A.; Betts, M.R.; Freeman, G.J.; Vignali, D.A.; Wherry, E.J. Coregulation of CD8+ T cell exhaustion by multiple inhibitory receptors during chronic viral infection. Nat. Immunol. 2009, 10, 29-37. [CrossRef] [PubMed]

83. Wakim, L.M.; Woodward-Davis, A.; Liu, R.; Hu, Y.; Villadangos, J.; Smyth, G.; Bevan, M.J. The molecular signature of tissue resident memory CD8 T cells isolated from the brain. J. Immunol. 2012, 189, 3462-3471. [CrossRef] [PubMed]

84. Corgnac, S.; Malenica, I.; Mezquita, L.; Auclin, E.; Voilin, E.; Kacher, J.; Halse, H.; Grynszpan, L.; Signolle, N.; Dayris, T.; et al. CD103(+)CD8(+) T(RM) cells accumulate in tumors of anti-PD-1-responder lung cancer patients and are tumor-reactive lymphocytes enriched with Tc17. Cell Rep. Med. 2020, 1, 100127. [CrossRef]

85. Duhen, T.; Duhen, R.; Montler, R.; Moses, J.; Moudgil, T.; De Miranda, N.F.; Goodall, C.P.; Blair, T.C.; Fox, B.A.; McDermott, J.E.; et al. Co-expression of CD39 and CD103 identifies tumor-reactive CD8 T cells in human solid tumors. Nat. Commun. 2018, 9, 2724. [CrossRef]

86. Gallerano, D.; Ciminati, S.; Grimaldi, A.; Piconese, S.; Cammarata, I.; Focaccetti, C.; Pacella, I.; Accapezzato, D.; Lancellotti, F.; Sacco, L.; et al. Genetically driven CD39 expression shapes human tumor-infiltrating CD8(+) T-cell functions. Int. J. Cancer 2020, 147, e33131. [CrossRef]

87. Wang, Z.; Wang, S.; Goplen, N.P.; Li, C.; Cheon, I.S.; Dai, Q.; Huang, S.; Shan, J.; Ma, C.; Ye, Z.; et al. PD-1(hi) CD8(+) resident memory T cells balance immunity and fibrotic sequelae. Sci. Immunol. 2019, 4, eaaw1217. [CrossRef]

88. Beyrend, G.; Van der Gracht, E.; Yilmaz, A.; Van Duikeren, S.; Camps, M.; Höllt, T.; Vilanova, A.; Van Unen, V.; Koning, F.; De Miranda, N.F.C.C.; et al. PD-L1 blockade engages tumor-infiltrating lymphocytes to co-express targetable activating and inhibitory receptors. J. Immunother. Cancer 2019, 7, 217. [CrossRef]

89. Roy, S.; Coulon, P.G.; Prakash, S.; Srivastava, R.; Geertsema, R.; Dhanushkodi, N.; Lam, C.; Nguyen, V.; Gorospe, E.; Nguyen, A.M.; et al. Blockade of PD-1 and LAG-3 immune checkpoints combined with vaccination restores the function of antiviral tissue-resident CD8(+) T(RM) cells and reduces ocular herpes simplex infection and disease in HLA transgenic rabbits. J. Virol. 2019, 93, e00827-19. [CrossRef]

90. Weisberg, S.P.; Carpenter, D.J.; Chait, M.; Dogra, P.; Gartrell-Corrado, R.D.; Chen, A.X.; Campbell, S.; Liu, W.; Saraf, P.; Snyder, M.E.; et al. Tissue-resident memory T cells mediate immune homeostasis in the human pancreas through the PD-1/PD-L1 pathway. Cell Rep. 2019, 29, 3916-3932.e3915. [CrossRef]

91. Gamradt, P.; Laoubi, L.; Nosbaum, A.; Mutez, V.; Lenief, V.; Grande, S.; Redoulès, D.; Schmitt, A.M.; Nicolas, J.F.; Vocanson, M. Inhibitory checkpoint receptors control CD8(+) resident memory T cells to prevent skin allergy. J. Allergy Clin. Immunol. 2019, 143, 2147-2157.e2149. [CrossRef] [PubMed]

92. Smolders, J.; Heutinck, K.M.; Fransen, N.L.; Remmerswaal, E.B.M.; Hombrink, P.; Ten Berge, I.J.M.; Van Lier, R.A.W.; Huitinga, I.; Hamann, J. Tissue-resident memory T cells populate the human brain. Nat. Commun. 2018, 9, 4593. [CrossRef] [PubMed]

93. Collins, A.V.; Brodie, D.W.; Gilbert, R.J.; Iaboni, A.; Manso-Sancho, R.; Walse, B.; Stuart, D.I.; Van der Merwe, P.A.; Davis, S.J. The interaction properties of costimulatory molecules revisited. Immunity 2002, 17, 201-210. [CrossRef]

94. Krummel, M.F.; Allison, J.P. CD28 and CTLA-4 have opposing effects on the response of T cells to stimulation. J. Exp. Med. 1995, 182, 459-465. [CrossRef] [PubMed]

95. Qureshi, O.S.; Zheng, Y.; Nakamura, K.; Attridge, K.; Manzotti, C.; Schmidt, E.M.; Baker, J.; Jeffery, L.E.; Kaur, S.; Briggs, Z.; et al. Trans-endocytosis of CD80 and CD86: A molecular basis for the cell-extrinsic function of CTLA-4. Science 2011, 332, 600-603. [CrossRef] [PubMed]

96. Kvistborg, P.; Philips, D.; Kelderman, S.; Hageman, L.; Ottensmeier, C.; Joseph-Pietras, D.; Welters, M.J.; van der Burg, S.; Kapiteijn, E.; Michielin, O.; et al. Anti-CTLA-4 therapy broadens the melanoma-reactive CD8+ T cell response. Sci. Transl. Med. 2014, 6, 254ra128. [CrossRef]

97. Pedicord, V.A.; Montalvo, W.; Leiner, I.M.; Allison, J.P. Single dose of anti-CTLA-4 enhances CD8+ T-cell memory formation, function, and maintenance. Proc. Natl. Acad. Sci. USA 2011, 108, 266-271. [CrossRef] 
98. Chen, L.; Sun, R.; Xu, J.; Zhai, W.; Zhang, D.; Yang, M.; Yue, C.; Chen, Y.; Li, S.; Turnquist, H.; et al. Tumor-derived IL33 promotes tissue-resident CD8(+) T cells and is required for checkpoint blockade tumor immunotherapy. Cancer Immunol. Res. 2020, 8 , 1381-1392. [CrossRef]

99. André, P.; Denis, C.; Soulas, C.; Bourbon-Caillet, C.; Lopez, J.; Arnoux, T.; Bléry, M.; Bonnafous, C.; Gauthier, L.; Morel, A.; et al. Anti-NKG2A mAb is a checkpoint inhibitor that promotes anti-tumor immunity by unleashing both $\mathrm{T}$ and NK cells. Cell 2018, 175, 1731-1743.e1713. [CrossRef]

100. Van Montfoort, N.; Borst, L.; Korrer, M.J.; Sluijter, M.; Marijt, K.A.; Santegoets, S.J.; Van Ham, V.J.; Ehsan, I.; Charoentong, P.; André, P.; et al. NKG2A blockade potentiates CD8 T cell immunity induced by cancer vaccines. Cell 2018, 175, 1744-1755.e1715. [CrossRef]

101. Chen, L.; Flies, D.B. Molecular mechanisms of T cell co-stimulation and co-inhibition. Nat. Rev. Immunol. 2013, 13, 227-242. [CrossRef] [PubMed]

102. Zhou, A.C.; Batista, N.V.; Watts, T.H. 4-1BB regulates effector CD8 T cell accumulation in the lung tissue through a TRAF1-, mTOR-, and antigen-dependent mechanism to enhance tissue-resident memory $\mathrm{T}$ cell formation during respiratory influenza infection. J. Immunol. 2019, 202, 2482-2492. [CrossRef] [PubMed]

103. Qu, Q.-X.; Zhu, X.-Y.; Du, W.-W.; Wang, H.-B.; Shen, Y.; Zhu, Y.-B.; Chen, C. 4-1BB agonism combined with PD-L1 blockade increases the number of tissue-resident CD8+ T cells and facilitates tumor abrogation. Front. Immunol. 2020, 11, 577. [CrossRef] [PubMed]

104. Salek-Ardakani, S.; Moutaftsi, M.; Sette, A.; Croft, M. Targeting OX40 promotes lung-resident memory CD8 T cell populations that protect against respiratory poxvirus infection. J. Virol. 2011, 85, 9051-9059. [CrossRef]

105. Zappasodi, R.; Sirard, C.; Li, Y.; Budhu, S.; Abu-Akeel, M.; Liu, C.; Yang, X.; Zhong, H.; Newman, W.; Qi, J.; et al. Rational design of anti-GITR-based combination immunotherapy. Nat. Med. 2019, 25, 759-766. [CrossRef]

106. Chu, K.L.; Batista, N.V.; Girard, M.; Law, J.C.; Watts, T.H. GITR differentially affects lung effector T cell subpopulations during influenza virus infection. J. Leukoc. Biol. 2020, 107, 953-970. [CrossRef]

107. Chu, K.L.; Batista, N.V.; Wang, K.C.; Zhou, A.C.; Watts, T.H. GITRL on inflammatory antigen presenting cells in the lung parenchyma provides signal 4 for T-cell accumulation and tissue-resident memory T-cell formation. Mucosal. Immunol. 2019, 12, 363-377. [CrossRef]

108. Oja, A.E.; Piet, B.; van der Zwan, D.; Blaauwgeers, H.; Mensink, M.; de Kivit, S.; Borst, J.; Nolte, M.A.; Van Lier, R.A.W.; Stark, R.; et al. Functional heterogeneity of CD4(+) tumor-infiltrating lymphocytes with a resident memory phenotype in NSCLC. Front. Immunol. 2018, 9, 2654. [CrossRef]

109. Christensen, J.E.; de Lemos, C.; Moos, T.; Christensen, J.P.; Thomsen, A.R. CXCL10 is the key ligand for CXCR3 on CD8+ effector $\mathrm{T}$ cells involved in immune surveillance of the lymphocytic choriomeningitis virus-infected central nervous system. J. Immunol. 2006, 176, 4235-4243. [CrossRef]

110. Hu, J.K.; Kagari, T.; Clingan, J.M.; Matloubian, M. Expression of chemokine receptor CXCR3 on T cells affects the balance between effector and memory CD8 T-cell generation. Proc. Natl. Acad. Sci. USA 2011, 108, E118-E127. [CrossRef]

111. Ferreira, C.; Barros, L.; Baptista, M.; Blankenhaus, B.; Barros, A.; Figueiredo-Campos, P.; Konjar, Š.; Lainé, A.; Kamenjarin, N.; Stojanovic, A.; et al. Type $1 \mathrm{~T}(\mathrm{reg})$ cells promote the generation of CD8(+) tissue-resident memory T cells. Nat. Immunol. 2020, 21, 766-776. [CrossRef] [PubMed]

112. Im, S.J.; Konieczny, B.T.; Hudson, W.H.; Masopust, D.; Ahmed, R. PD-1+ stemlike CD8 T cells are resident in lymphoid tissues during persistent LCMV infection. Proc. Natl. Acad. Sci. USA 2020, 117, 4292-4299. [CrossRef] [PubMed]

113. Wein, A.N.; McMaster, S.R.; Takamura, S.; Dunbar, P.R.; Cartwright, E.K.; Hayward, S.L.; McManus, D.T.; Shimaoka, T.; Ueha, S.; Tsukui, T.; et al. CXCR6 regulates localization of tissue-resident memory CD8 T cells to the airways. J. Exp. Med. 2019, 216, 2748-2762. [CrossRef] [PubMed]

114. Holz, L.E.; Chua, Y.C.; De Menezes, M.N.; Anderson, R.J.; Draper, S.L.; Compton, B.J.; Chan, S.T.S.; Mathew, J.; Li, J.; Kedzierski, L.; et al. Glycolipid-peptide vaccination induces liver-resident memory CD8+ T cells that protect against rodent malaria. Sci. Immunol. 2020, 5, eaaz8035. [CrossRef]

115. Shin, H.; Iwasaki, A. A vaccine strategy that protects against genital herpes by establishing local memory T cells. Nature 2012, 491, 463-467. [CrossRef]

116. Onuffer, J.J.; Horuk, R. Chemokines, chemokine receptors and small-molecule antagonists: Recent developments. Trends Pharmacol. Sci. 2002, 23, 459-467. [CrossRef]

117. Szekanecz, Z.; Koch, A.E. Successes and failures of chemokine-pathway targeting in rheumatoid arthritis. Nat. Rev. Rheumatol. 2016, 12, 5-13. [CrossRef]

118. Zhang, N.; Bevan, M.J. Transforming growth factor-beta signaling controls the formation and maintenance of gut-resident memory $\mathrm{T}$ cells by regulating migration and retention. Immunity 2013, 39, 687-696. [CrossRef]

119. Sheridan, B.S.; Pham, Q.M.; Lee, Y.T.; Cauley, L.S.; Puddington, L.; Lefrancois, L. Oral infection drives a distinct population of intestinal resident memory CD8(+) T cells with enhanced protective function. Immunity 2014, 40, 747-757. [CrossRef]

120. Hirai, T.; Yang, Y.; Zenke, Y.; Li, H.; Chaudhri, V.K.; De La Cruz Diaz, J.S.; Zhou, P.Y.; Nguyen, B.A.; Bartholin, L.; Workman, C.J.; et al. Competition for active TGF $\beta$ cytokine allows for selective retention of antigen-specific tissue- resident memory $\mathrm{T}$ cells in the epidermal niche. Immunity 2020. [CrossRef] 
121. Nath, A.P.; Braun, A.; Ritchie, S.C.; Carbone, F.R.; Mackay, L.K.; Gebhardt, T.; Inouye, M. Comparative analysis reveals a role for TGF-beta in shaping the residency-related transcriptional signature in tissue-resident memory CD8+ T cells. PLoS ONE 2019, 14, e0210495. [CrossRef] [PubMed]

122. Borges da Silva, H.; Peng, C.; Wang, H.; Wanhainen, K.M.; Ma, C.; Lopez, S.; Khoruts, A.; Zhang, N.; Jameson, S.C. Sensing of ATP via the purinergic receptor P2RX7 promotes CD8(+) Trm cell generation by enhancing their sensitivity to the cytokine TGF- $\beta$. Immunity 2020, 53, 158-171.e156. [CrossRef] [PubMed]

123. Thompson, E.A.; Darrah, P.A.; Foulds, K.E.; Hoffer, E.; Caffrey-Carr, A.; Norenstedt, S.; Perbeck, L.; Seder, R.A.; Kedl, R.M.; Loré, K. Monocytes acquire the ability to prime tissue-resident T cells via IL-10-mediated TGF- $\beta$ release. Cell Rep. 2019, 28, 1127-1135.e1124. [CrossRef] [PubMed]

124. Nizard, M.; Roussel, H.; Diniz, M.O.; Karaki, S.; Tran, T.; Voron, T.; Dransart, E.; Sandoval, F.; Riquet, M.; Rance, B.; et al. Induction of resident memory $\mathrm{T}$ cells enhances the efficacy of cancer vaccine. Nat. Commun. 2017, 8, 15221. [CrossRef]

125. Schenkel, J.M.; Fraser, K.A.; Casey, K.A.; Beura, L.K.; Pauken, K.E.; Vezys, V.; Masopust, D. IL-15-independent maintenance of tissue-resident and boosted effector memory CD8 T cells. J. Immunol. 2016, 196, 3920-3926. [CrossRef]

126. Holz, L.E.; Prier, J.E.; Freestone, D.; Steiner, T.M.; English, K.; Johnson, D.N.; Mollard, V.; Cozijnsen, A.; Davey, G.M.; Godfrey, D.I.; et al. CD8+ T cell activation leads to constitutive formation of liver tissue-resident memory $\mathrm{T}$ cells that seed a large and flexible niche in the liver. Cell Rep. 2018, 25, 68-79.e64. [CrossRef]

127. Adachi, T.; Kobayashi, T.; Sugihara, E.; Yamada, T.; Ikuta, K.; Pittaluga, S.; Saya, H.; Amagai, M.; Nagao, K. Hair follicle-derived IL-7 and IL-15 mediate skin-resident memory T cell homeostasis and lymphoma. Nat. Med. 2015, 21, 1272-1279. [CrossRef]

128. Sowell, R.T.; Goldufsky, J.W.; Rogozinska, M.; Quiles, Z.; Cao, Y.; Castillo, E.F.; Finnegan, A.; Marzo, A.L. IL-15 complexes induce migration of resting memory CD8 T cells into mucosal tissues. J. Immunol. 2017, 199, 2536-2546. [CrossRef]

129. Zaid, A.; Mackay, L.K.; Rahimpour, A.; Braun, A.; Veldhoen, M.; Carbone, F.R.; Manton, J.H.; Heath, W.R.; Mueller, S.N. Persistence of skin-resident memory T cells within an epidermal niche. Proc. Natl. Acad. Sci. USA 2014, 111, 5307-5312. [CrossRef]

130. Boddupalli, C.S.; Nair, S.; Gray, S.M.; Nowyhed, H.N.; Verma, R.; Gibson, J.A.; Abraham, C.; Narayan, D.; Vasquez, J.; Hedrick, C.C.; et al. ABC transporters and NR4A1 identify a quiescent subset of tissue-resident memory T cells. J. Clin. Investig. 2016, 126, 3905-3916. [CrossRef]

131. Li, Y.; Innocentin, S.; Withers, D.R.; Roberts, N.A.; Gallagher, A.R.; Grigorieva, E.F.; Wilhelm, C.; Veldhoen, M. Exogenous stimuli maintain intraepithelial lymphocytes via aryl hydrocarbon receptor activation. Cell 2011, 147, 629-640. [CrossRef] [PubMed]

132. Kim, J.H.; Han, J.W.; Choi, Y.J.; Rha, M.S.; Koh, J.Y.; Kim, K.H.; Kim, C.G.; Lee, Y.J.; Kim, A.R.; Park, J.; et al. Functions of human liver CD69(+)CD103(-)CD8(+) T cells depend on HIF-2 $\alpha$ activity in healthy and pathologic livers. J. Hepatol. 2020, 72, 1170-1181. [CrossRef] [PubMed]

133. Lin, R.; Zhang, H.; Yuan, Y.; He, Q.; Zhou, J.; Li, S.; Sun, Y.; Li, D.Y.; Qiu, H.-B.; Wang, W.; et al. Fatty acid oxidation controls CD8+ tissue-resident memory T-cell survival in gastric adenocarcinoma. Cancer Immunol. Res. 2020, 8, 479-492. [CrossRef] [PubMed]

134. Pearce, E.L.; Walsh, M.C.; Cejas, P.J.; Harms, G.M.; Shen, H.; Wang, L.-S.; Jones, R.G.; Choi, Y. Enhancing CD8 T-cell memory by modulating fatty acid metabolism. Nature 2009, 460, 103-107. [CrossRef] [PubMed]

135. O'Sullivan, D.; Van der Windt, G.J.W.; Huang, S.C.; Curtis, J.D.; Chang, C.H.; Buck, M.D.; Qiu, J.; Smith, A.M.; Lam, W.Y.; DiPlato, L.M.; et al. Memory CD8(+) T cells use cell-Intrinsic lipolysis to support the metabolic programming necessary for development. Immunity 2018, 49, 375-376. [CrossRef]

136. Cui, G.; Staron, M.M.; Gray, S.M.; Ho, P.-C.; Amezquita, R.A.; Wu, J.; Kaech, S.M. IL-7-induced glycerol transport and TAG synthesis promotes memory CD8+ T cell longevity. Cell 2015, 161, 750-761. [CrossRef]

137. Kumar, B.V.; Ma, W.; Miron, M.; Granot, T.; Guyer, R.S.; Carpenter, D.J.; Senda, T.; Sun, X.; Ho, S.H.; Lerner, H.; et al. Human tissue-resident memory $\mathrm{T}$ cells are defined by core transcriptional and functional signatures in lymphoid and mucosal sites. Cell Rep. 2017, 20, 2921-2934. [CrossRef]

138. Park, C.O.; Kupper, T.S. The emerging role of resident memory T cells in protective immunity and inflammatory disease. Nat. Med. 2015, 21, 688-697. [CrossRef] 